\title{
Effect of storage and separation of milk at udder quarter level on milk composition, proteolysis, and coagulation properties in relation to somatic cell count
}

\author{
L. Forsbäck, ${ }^{* 1}$ H. Lindmark-Månsson,† K. Svennersten-Sjaunja, ${ }^{*}$ L. Bach Larsen,‡ and A. Andrén§ \\ *Swedish University of Agricultural Sciences, Department of Animal Nutrition and Management, SE-753 23 Uppsala, Sweden \\ †Swedish Dairy Association, SE-223 70 Lund, Sweden \\ $\ddagger$ Aarhus University, Department of Food Science, DK-8830 Tjele, Denmark \\ $\S$ Swedish University of Agricultural Sciences, Department of Food Science, SE-750 07 Uppsala, Sweden
}

\section{ABSTRACT}

Coagulation properties of milk are altered by elevated somatic cell count (SCC), partly due to increased proteolytic and lipolytic activity in the milk and, thereby, degradation of protein and fat during storage. Milk is commonly stored on the farm at cooling conditions for up to $2 \mathrm{~d}$ before transport to the dairy for processing. This study evaluated the effects of storage on milk with altered composition due to high SCC and the effects of exclusion of milk from individual udder quarters with high SCC on milk composition, proteolysis, and coagulation properties. Udder-quarter milk and cowcomposite milk samples from 13 cows having at least 1 quarter with SCC above 100,000 cells $/ \mathrm{mL}$ were collected on 1 occasion. In addition, commingled milk from only healthy quarters $(<100,000$ cells $/ \mathrm{mL})$ of each cow was collected, representing a cow sample where milk with elevated SCC was excluded. The milk samples were analyzed for total protein content; protein content in the whey fraction; casein, fat, and lactose contents; SCC; proteolysis; curd yield; coagulation time; and total bacterial count, on the day of sampling and after 2 and $5 \mathrm{~d}$ of storage at $+4^{\circ} \mathrm{C}$. In addition to SCC, duration of storage and total bacterial count had an effect on milk quality. The content of total protein, fat and protein contents in the whey fraction, and curd yield were found to have different storage characteristics depending on the level of SCC at udder-quarter level. The exclusion of milk from udder quarters with elevated SCC decreased the content of total protein and protein content in the whey fraction and increased the content of lactose at cow level. However, the effect of separating milk at udder-quarter level needs to be further studied at bulk tank level to evaluate the effect on overall total milk quality.

Received March 18, 2011.

Accepted July 23, 2011.

${ }^{1}$ Corresponding author: Linda.Forsback@slu.se
Key words: dairy cow, milk composition, udder quarter, storage

\section{INTRODUCTION}

Poor milk quality originating from individual cows at farm level cannot be compensated for by processing. Therefore, high raw milk quality is necessary to achieve a large quantity of high-quality products in the dairy industry (Harding, 1995). Milk quality is influenced by several factors but one major factor is mastitis, which is the most prevalent and economically important production disease in dairy cattle worldwide today (Halasa et al., 2007).

Mastitis has a negative effect on milk composition and yield. Common effects of mastitis in milk include increased SCC, increased whey protein content, and decreased content of lactose and CN (for review see Kitchen, 1981; Munro et al., 1984; Hortet and Seegers, 1998). The change in milk composition influences the processing properties of the milk; for example, giving lower cheese yield, CN loss into whey, and slower curd formation (Barbano et al., 1991; Auldist et al., 1996; Leitner et al., 2008). Milk with high SCC has elevated enzyme activity, which contributes to increased proteolysis and lipolysis, both before milking in the udder and after milking during storage (Bastian and Brown, 1996; Le Roux et al., 2003; Deeth, 2006).

Mastitis can be either clinical or subclinical, with both forms affecting milk quality. As clinical mastitis gives visible signs in the milk, it is possible to detect and exclude milk from cows with clinical mastitis by visual inspection of the foremilk. However, subclinical mastitis has no visible signs and, therefore, represents a higher risk of these cows going unnoticed (Akers, 2002). Furthermore, milk from subclinically infected cows can enter the bulk tank without the farmer's knowledge and consequently contribute to impaired milk quality. Earlier studies reported that milk composition had deteriorated in individual udder quarters from cows with low to moderate cow SCC (Berglund et al., 2004; Forsbäck 
et al., 2010). These studies indicated that milk should be analyzed at udder-quarter level to detect quarters with a risk of unfavorable milk composition. Furthermore, indications were that detection and separation during milking of milk from individual udder quarters with deteriorated composition, increased enzymatic activity, and high SCC would improve the overall milk quality.

Many previous studies have focused on milk composition in relation to SCC in fresh milk, but fewer studies exist evaluating milk composition and processing properties after storage. In modern production, milk is usually stored at cooling conditions on the farm up to $2 \mathrm{~d}$ and then transported to the dairy for processing. Consequently, the milk used for cheese and yogurt production is stored for some days before being processed. Because milk from individual quarters with changed composition and elevated enzyme activities is mixed with milk of good quality in the bulk tank, the affected milk contributes to altering the composition of all milk during storage. Milk from bulk tanks is reported to deteriorate much faster during storage than milk from bacteria-free glands of individual cows (Leitner et al., 2008). Therefore, it is important to study the effects of storing milk with altered composition due to high SCC. In addition, the effect of separation of milk from individual udder quarters with high SCC and deteriorated composition must be evaluated to decide whether this would improve overall milk quality.

The aim of this study was to evaluate milk composition, proteolysis, and coagulation properties both before and during storage of milk from individual udder quarters. Cow-composite milk and commingled milk from the healthy quarters of each cow were also evaluated for the same purpose. The hypothesis was that milk from individual udder quarters with elevated SCC and individual cows with elevated SCC in their composite milk would deteriorate much faster during storage than milk from healthy quarters and commingled milk from only healthy udder quarters.

\section{MATERIALS AND METHODS}

The study was performed at Kungsängen Research Centre, Swedish University of Agricultural Sciences, Uppsala, Sweden. The study was approved by the Uppsala Ethics Committee.

\section{Animals}

The study included 13 cows of the Swedish Red Breed. A total of 34 cows were tested before the trial started to find cows that fulfilled the pre-set criteria, which were cows having 1 or 2 udder quarters with SCC $>100,000$ cells $/ \mathrm{mL}$ and the other quarters with $\mathrm{SCC}<100,000$ cells $/ \mathrm{mL}$; in addition, the udder quarters with elevated SCC should have at least 3-fold higher SCC than their healthy counterparts. The mean lactation number and lactation week \pm standard deviation for all 13 cows were $3.1 \pm 1.6$ and $19 \pm 15$, respectively. The cows were kept in 2 different housing systems, one stanchion barn and one loose house barn equipped with automatic milking (AM). The cows in the AM barn were milked, on average, 2.3 times per day, with an average milking interval of $10.3 \mathrm{~h}$ and a range of 5.1 to $14.7 \mathrm{~h}$. The cows in the stanchion barn were milked twice daily with a milking interval of $9 \mathrm{~h}$ during the daytime and $15 \mathrm{~h}$ during the nighttime. The cows were fed according to Swedish recommendations (Spörndly, 2003). All cows included in the study delivered milk to the dairy on the sampling occasions and none of the cows was treated for mastitis.

\section{Milking Equipment}

The cows in the AM barn were milked with a Voluntary Milking System (VMS, provided by DeLaval International $\mathrm{AB}$, Tumba, Sweden) with monovac (same vacuum level throughout milking), pulsation ratio $70 / 30$, pulsation rate 60 cycles/minute, and system vacuum $42 \mathrm{kPa}$. The cows in the stanchion barns were milked with a special quarter milking machine (provided by DeLaval International $\mathrm{AB}$ ) with monovac, pulsation ratio $70 / 30$, pulsation rate 60 cycles/minute, and system vacuum $42 \mathrm{kPa}$. Each udder quarter was milked separately and milking finished individually on each quarter when milk flow was approximately $300 \mathrm{~g} /$ min.

\section{Milk Sampling and Recording}

To find cows that fulfilled the criteria for participation in the experiment (see above), 34 cows were milked once and the milk from each udder quarter was analyzed for SCC. From cows that fulfilled the criteria (n $=13$ ), new milk samples from 1 milking occasion were collected on the following day. In both milking systems and during all sampling, all of the milk obtained during the entire milking from each individual udder quarter was collected in separate containers. Udder-quarter milk samples and 2 different cow-composite milk samples (cow composite and cow separated) from each cow were collected for analysis. The following sampling procedure was used for quarter milk samples: after gentle stirring, milk samples were collected from each quarter container. To collect the cow-composite milk samples, an amount of milk proportional to the milk yield produced by each udder quarter was poured into a new 
container and mixed, and after gentle stirring, a sample was taken. Cow-separated milk samples corresponded to a cow-composite milk sample where milk from udder quarters with elevated SCC and deteriorated composition was excluded. These cow-separated milk samples were collected by taking an amount of milk proportional to the total milk yield of each udder quarter with $\mathrm{SCC}<100,000$ cells/mL from the individual cows; this milk was poured into a new container and mixed, and after gentle stirring, a sample was taken. The number of samples collected of quarter milk, cow-composite milk, and cow-separated milk were 156, 33, and 33, respectively.

Milk samples for gross composition, SCC, proteolysis, coagulation properties, and total bacteria count were analyzed on the day of sampling (d 0) and in stored milk after $48 \mathrm{~h} \mathrm{(d} \mathrm{2)} \mathrm{and} 120 \mathrm{~h}(\mathrm{~d} 5)$ of storage. During storage, the milk was gently stirred for $15 \mathrm{~min}$ every hour and the temperature was set to $+4^{\circ} \mathrm{C}$ to imitate the storage and stirring in farm bulk tanks. Milk samples for gross composition, SCC, and coagulation properties were analyzed after the different storage times. Milk samples for proteolysis analysis and total bacteria count were frozen in $-80^{\circ} \mathrm{C}$ after the different storage times and stored in this condition until analysis.

On the day of sampling and the following day, bacteriological samples were collected from all udder quarters of the 13 cows directly after milking had finished. The milk used for bacteriological analysis was collected in sterile tubes directly from the teats. Samples were collected according to the following routine: the teats were wiped with an udder towel, the first beams of milk were rejected, and then the teats were disinfected with $70 \%$ ethanol and allowed to dry before milk collection.

\section{Analysis of SCC, Fat, Total Protein, Lactose, and Whey Protein}

The milk samples were analyzed for SCC using electronic fluorescence-based cell counting (Fossomatic 5000; N. Foss Electric A/S, Hillerød, Denmark). Before measurement of SCC, the instrument was controlled with 2 different reference milk samples (Eurofins Steins Laboratorium A/S, Holstebro, Denmark) containing different levels of SCC. The mid-infrared spectroscopy method (Fourier Transform Instrument, FT 120; Foss Electric A/S) was used for the determination of milk composition (i.e. fat, total protein, lactose, and protein content in the whey fraction). Control of the instrument was performed before measurement with 3 different reference milk samples (Eurofins Steins Laboratorium A/S) with different milk compositions. To determine the protein content in the whey fraction, rennet was added to the milk samples and, after co- agulation, protein was analyzed in the whey protein fraction by mid-infrared spectroscopy according to a rennet CN method described by Forsbäck et al. (2009). As the whey fraction of the milk samples will contain both whey proteins and degradation products from $\mathrm{CN}$ after storage, the result of this analysis is designated as protein content in the whey fraction. The proportion of $\mathrm{CN}$ was calculated from the protein content in the whey fraction and the total protein content. The CN number was calculated as the proportion of $\mathrm{CN}$ in relation to total protein.

\section{Analysis of Proteolysis Products}

The products of proteolysis were determined by analysis of the level of free amino terminals, using the fluorescamine method described by Wiking et al. (2002), in acid whey prepared from skim milk samples by addition of $0.1 \mathrm{~mL}$ of $10 \% \mathrm{CH}_{3} \mathrm{COOH}$ and $0.1 \mathrm{~mL}$ of $1 \mathrm{~N} \mathrm{CH}_{3} \mathrm{COOHNa}$ to $\mathrm{pH} 4.6$. Whey was recovered by centrifugation at $1,500 \times g$ for $10 \mathrm{~min}$ at $5^{\circ} \mathrm{C}$. The level of proteolysis in the samples was expressed as $\mathrm{m} M$ Leu equivalents using a Leu standard curve.

\section{Curd Yield and Coagulation Time}

A cheese-making model similar to that of Hallén et al. (2010) was used to measure yield and DM of the curd. In contrast to Hallén et al. (2010), whole milk samples were used and the DM of the curd was determined as follows: after weighing and decanting of the whey, the remaining curd was removed and weighed before incubation at $105^{\circ} \mathrm{C}$ overnight. The dried curd was weighed warm on the following day.

The coagulation time was estimated by recording the time taken for visible flocculation of the milk samples after rennet addition, with the same individual performing this test throughout the whole experiment. The milk samples $(10 \mathrm{~mL})$ were preheated in a water bath at $30^{\circ} \mathrm{C}$. A $25-\mu \mathrm{L}$ portion of chymosin solution (Chymax Plus, $190 \mathrm{IMCU} / \mathrm{ml}$; Chr. Hansen A/S, Hørsholm, Denmark) was added and mixed with the milk sample. The milk sample was stirred slowly until the milk coagulated and the time was recorded.

\section{Bacteria}

Bacteriological analysis of milk samples collected directly from each udder quarter was performed mainly with PathoProof Mastitis PCR Assay (Finnzymes Oy, Espoo, Finland) according to Koskinen et al. (2009). The bacteriological analysis of the milk samples from 3 of the cows was performed by the National Veterinary Institute (Uppsala, Sweden), according to quality as- 
surance protocol SS-EN ISO/IEC 17025. During sampling of the first 3 cows, conventional bacteriological analyses were performed, but because this method was not successful in finding bacteria, the PathoProof Mastitis PCR Assay was introduced.

Total bacteria plate count (presented as colonyforming units per milliliter) was performed on all milk samples.

\section{Statistical Analyses}

The effects of cow, day of storage, total bacteria count, SCC, and the interaction of SCC and day of storage on milk composition, proteolysis, and coagulation properties were calculated in all udder-quarter milk samples using the MIXED procedure in SAS 9.1 (SAS Institute, 2004) with repeated statement. In addition, the effects of cow, day of storage, total bacteria count, separation of udder quarters with elevated SCC and the interaction between day of storage and separation of udder quarters with elevated SCC on milk composition, proteolysis and coagulation properties were calculated in all cow-composite and cow-separated milk samples using the MIXED procedure in SAS 9.1 with repeated statement.

The differences in milk composition, proteolysis, and coagulation properties between udder quarters with elevated SCC and contralateral healthy quarters for individual cows were calculated and tested to determine whether they differed from zero using the paired $t$-test in SAS 9.1. Logarithmic values of SCC and total bacteria count were used in all statistical calculations.

\section{RESULTS}

The 13 cows included in this study had 1 or 2 udder quarters with elevated SCC and, in the majority of the cows, infection by mastitis bacteria was confirmed in these udder quarters (see Table 1). The SCC in the affected udder quarters had a mean value 713,100 cells / $\mathrm{mL}$ (displayed as antilogarithmic value). The mean value of SCC in the contralateral healthy quarters was 17,800 cells/mL (displayed as antilogarithmic value).

\section{Udder-Quarter Milk Samples}

The mean values of the parameters measured in all quarter milk samples after different durations of storage and the probabilities of the different effects are presented in Table 2. The duration of storage affected the content of total protein, $\mathrm{CN}$, and fat; proteolysis; and curd yield. Proteolysis increased and total protein content showed a small increase after storage, whereas $\mathrm{CN}$, fat, and curd yield decreased. Parameters affected by the total bacteria count of the milk samples were $\mathrm{CN}$ number (the proportion of $\mathrm{CN}$ in relation to total protein), lactose and fat content, proteolysis, and curd yield. Casein number, lactose, fat, and curd yield decreased with increasing bacteria count, whereas proteolysis increased. The level of SCC in the milk affected the protein content in the whey fraction, lactose content, proteolysis, and curd yield. The protein content in the whey fraction, proteolysis, and curd yield increased with elevated SCC, whereas the lactose content decreased. The interaction between SCC and storage

Table 1. Somatic cell counts and udder pathogens detected in udder quarters with elevated SCC in the 13 cows included in the study

\begin{tabular}{|c|c|c|c|}
\hline Cow & Quarter $^{1}$ & $\begin{array}{c}\mathrm{SCC} \\
\text { (cells } / \mathrm{mL} \text { ) }\end{array}$ & $\begin{array}{l}\text { Detected udder } \\
\text { pathogens }\end{array}$ \\
\hline A & $\mathrm{RR}$ & $2,302,000$ & Enterobacter cloacae \\
\hline B & $\mathrm{RR}$ & 936,000 & Negative \\
\hline $\mathrm{C}$ & $\mathrm{RR}$ & 322,000 & Streptococcus uberis \\
\hline $\mathrm{D}$ & $\mathrm{RR}$ & 278,000 & CNS \\
\hline $\mathrm{E}$ & $\mathrm{RF}$ & 845,000 & Strep. uberis/Streptococcus dysgalactiae \\
\hline $\mathrm{E}$ & $\mathrm{RR}$ & 352,000 & CNS \\
\hline $\mathrm{F}$ & $\mathrm{RR}$ & $9,282,000$ & CNS \\
\hline G & LR & 148,000 & Staphylococcus aureus \\
\hline $\mathrm{H}$ & $\mathrm{RF}$ & $1,423,000$ & CNS \\
\hline $\mathrm{H}$ & LR & 325,000 & CNS \\
\hline I & $\mathrm{LF}$ & $2,783,000$ & Strep. uberis/CNS \\
\hline $\mathrm{J}$ & $\mathrm{RR}$ & 395,000 & CNS \\
\hline $\mathrm{K}$ & LR & $2,137,000$ & Strep. uberis \\
\hline $\mathrm{L}$ & LF & 214,000 & Strep. dysgalactiae \\
\hline $\mathrm{L}$ & $\mathrm{LR}^{2}$ & 767,000 & CNS \\
\hline $\mathrm{M}$ & $\mathrm{RF}$ & 303,000 & CNS/Corynebacterium bovis \\
\hline M & $\mathrm{LR}^{2}$ & 748,000 & $\mathrm{CNS} /$ C. bovis \\
\hline
\end{tabular}


Table 2. Mean values of milk composition, proteolysis, and coagulation properties in all udder-quarter samples on different days of storage ${ }^{1}$

\begin{tabular}{|c|c|c|c|c|c|c|c|c|}
\hline Property & $\begin{array}{l}\text { Storage } \\
\text { d } 0\end{array}$ & $\begin{array}{c}\text { Storage } \\
\text { d } 2\end{array}$ & $\begin{array}{c}\text { Storage } \\
\text { d } 5\end{array}$ & Cow & $\begin{array}{l}\text { Storage } \\
\text { day }\end{array}$ & $\mathrm{TBC}$ & $\mathrm{SCC}$ & $\begin{array}{c}\mathrm{SCC} \times \\
\text { storage day }\end{array}$ \\
\hline Total protein $(\%)$ & 3.27 & 3.29 & 3.29 & 0.0675 & $<0.0001$ & NS & 0.0724 & $<0.0001$ \\
\hline $\mathrm{CN}(\%)$ & 2.38 & 2.38 & 2.36 & 0.0397 & $<0.0001$ & NS & NS & $<0.0001$ \\
\hline CN number ${ }^{3}$ & 0.73 & 0.73 & 0.72 & NS & NS & $<0.0001$ & NS & NS \\
\hline Lactose (\%) & 4.74 & 4.76 & 4.77 & 0.0598 & NS & $<0.0001$ & $<0.0001$ & NS \\
\hline Fat $(\%)$ & 3.83 & 3.65 & 3.61 & 0.0653 & $<0.0001$ & $<0.0001$ & NS & $<0.0001$ \\
\hline
\end{tabular}

${ }^{1}$ Results are presented as least squares means for each day of storage and probabilities of the effects of cow, storage day, total bacteria count $(\mathrm{TBC}), \mathrm{SCC}$, and the interaction of SCC $\times$ storage day $(\mathrm{n}=156)$.

${ }^{2}$ The protein content in the whey fraction.

${ }^{3}$ Proportion of $\mathrm{CN}$ in relation to total protein.

duration affected the content of total protein, fat, and $\mathrm{CN}$; protein content in the whey fraction; and curd yield. The mean values of total bacteria count of all udder-quarter milk samples was 3.61, 4.19, and $5.77 \log$ $\mathrm{cfu} / \mathrm{mL}$ for storage d 0,2 , and 5 , respectively.

Milk composition, proteolysis, and coagulation properties of udder quarters with elevated SCC and those of the contralateral healthy udder quarters of the same cow after the different time periods of storage are presented in Table 3 . The protein content in the whey fraction, lactose content, and $\mathrm{CN}$ number differed significantly between healthy and affected udder quarters for all periods of storage. The $\mathrm{CN}$ number and lactose content were higher and the protein content in the whey fraction was lower in healthy udder quarters. The total protein content in milk from affected quarters was significantly higher than in milk from healthy quarters, both at $\mathrm{d} 0$ and at $\mathrm{d} 2$ after storage, whereas after $5 \mathrm{~d}$ of storage, a tendency occurred toward a higher protein content in milk from the affected quarters. Furthermore, the level of proteolysis was higher in milk from affected quarters, both in milk stored for 0 or 2 $\mathrm{d}$ and showed a tendency to be higher in milk stored for $5 \mathrm{~d}$ compared with milk from healthy quarters. The $\mathrm{CN}$ content showed a tendency to be lower in affected udder quarters than in healthy quarters in milk after 2 and $5 \mathrm{~d}$ of storage. Curd yield showed a tendency to be higher in milk obtained from affected udder quarters than from healthy quarters after $5 \mathrm{~d}$ of storage.

\section{Cow-Composite and Cow-Separated Milk Samples}

The mean value of SCC in the cow-composite and cow-separated milk samples was 294,000 and 17,000 cells/mL (displayed as antilogarithmic values), respectively. The mean milk yield of cow-composite and cow-separated milk samples was $16.7 \mathrm{~kg}$ and $11.5 \mathrm{~kg}$, respectively. The probabilities of the effects on milk composition, proteolysis, and coagulation properties of all cow-composite and cow-separated milk samples are presented in Table 4. Total protein, lactose, and fat contents; protein content in the whey fraction; prote-

Table 3. Milk composition, proteolysis, and coagulation properties of udder-quarter milk samples ${ }^{1}$

\begin{tabular}{|c|c|c|c|c|c|c|c|c|c|}
\hline Property & \multicolumn{3}{|c|}{ Storage d 0} & \multicolumn{3}{|c|}{ Storage d 2} & \multicolumn{3}{|c|}{ Storage d 5} \\
\hline Total protein $(\%)$ & 3.33 & 3.27 & $*$ & 3.34 & 3.29 & $*$ & 3.35 & 3.30 & $\dagger$ \\
\hline Whey fraction ${ }^{3}(\%)$ & 0.95 & 0.87 & $* * *$ & 0.97 & 0.88 & $* * *$ & 1.00 & 0.92 & $* * *$ \\
\hline CN number ${ }^{4}$ & 0.72 & 0.73 & $* * *$ & 0.72 & 0.75 & $* * *$ & 0.70 & 0.72 & $* * *$ \\
\hline Lactose (\%) & 4.61 & 4.79 & $* * *$ & 4.63 & 4.81 & $* * *$ & 4.63 & 4.79 & $* * *$ \\
\hline Curd yield $(\mathrm{g}$ of $\mathrm{DM} / \mathrm{g})$ & 0.14 & 0.15 & NS & 0.13 & 0.12 & NS & 0.14 & 0.11 & $\dagger$ \\
\hline Coagulation time (min) & 6.82 & 7.09 & NS & 17.76 & 24.32 & NS & 18.38 & 18.97 & NS \\
\hline \multicolumn{10}{|c|}{$\begin{array}{l}{ }^{1} \text { Results are presented as mean values of affected and healthy udder quarters and significance of paired } t \text {-tests for the different storage days } \\
=17) \text {. }\end{array}$} \\
\hline
\end{tabular}


olysis; curd yield; and coagulation time depended on the individual cow from which the milk was collected. The duration of storage affected the protein content in the whey fraction and fat content, CN number, and coagulation time. The protein content in the whey fraction and coagulation time increased during storage, whereas fat content and $\mathrm{CN}$ number decreased. The fat content decreased with increasing total bacteria count in the milk samples. The exclusion of milk from udder quarters with elevated SCC decreased the total protein content and the protein content in the whey fraction and increased the content of lactose (Table 5). The mean values of total bacteria count of all cowcomposite and cow-separated milk samples was 3.88 , 4.67, and $6.06 \log \mathrm{cfu} / \mathrm{mL}$ for storage d 0,2 , and 5 , respectively.

\section{DISCUSSION}

Exclusion of milk from individual udder quarters with elevated SCC affected the total protein and lactose contents and the protein content in the whey fraction at cow level. No statistically significant effects of such exclusion were observed on the proteolysis and coagulation properties of milk. However, altered milk composition, including increased content of whey protein, has been shown to have a negative effect on processing, including cheese yield (Munro et al., 1984; Auldist et al., 1996; Roupas, 2001). Furthermore, some indications exist that separating milk at udder-quarter level might generate a better quality of milk for processing, although we were unable to demonstrate such an effect in this relatively small study. This needs to be further studied at the bulk-tank level, to evaluate the total outcome of separating out milk with deteriorated composition and elevated SCC at the udder-quarter level.

\section{Duration of Storage}

In udder-quarter, cow-composite, and cow-separated milk samples, the $\mathrm{CN}$ and fat contents were significantly decreased by the duration of cold storage. In udderquarter milk samples, total protein content, proteolysis, and curd yield were affected by storage, and a storage effect occurred on the protein content of the whey fraction, CN number, and coagulation time in cow-composite and cow-separated milk samples. Naturally, in this kind of study, the number of quarter-milk samples is much higher than the samples at cow level, which can explain some of the differing results at quarter and cow level. All of the parameters affected are, in one way or another, associated with proteolysis and lipolysis in milk. It is well known that SCC and mastitis are associated with increased proteolytic and lipolytic activity (Auldist and Hubble, 1998; Le Roux et al., 2003; Santos et al., 2003). The decreased fat content of milk due to storage is probably an effect of creaming but could also be an effect of lipolysis, which has been shown in an earlier study (Sjaunja, 1984). Although the milk has been stirred during storage, some creaming will always occur, which explains the decreased fat content. The creaming will result in a lower volume of the water phase of the milk samples, which could be one explanation of the somewhat higher contents of both protein and lactose due to storage. In addition, it has been shown that the lactose content will increase in milk with elevated lipolysis. Fatty acids with low molecular weight that might occur in milk after lipolysis are miscible in milk and form some part of the acid $\left(\mathrm{RCOO}^{-}\right)$ in the dissociated form; thus, this will be absorbed at the protein wavelength in mid-infrared spectroscopy (Sjaunja, 1984). The increased total protein content of milk due to storage in our study might be an effect of

Table 4. Probabilities of effects on milk composition, proteolysis, and coagulation properties in cow-composite and cow-separated milk samples ${ }^{1}$

\begin{tabular}{lccccc}
\hline Property & Cow & $\begin{array}{c}\text { Storage } \\
\text { time }\end{array}$ & TBC & $\begin{array}{c}\text { Separation } \\
\text { of milk }\end{array}$ & $\begin{array}{c}\text { Separation of milk } \\
\times \text { storage time }\end{array}$ \\
\hline Total protein $(\%)$ & 0.0351 & NS & NS & 0.0001 & NS \\
CN $(\%)$ & 0.0853 & 0.0162 & NS & NS & NS \\
Whey fraction $^{2}(\%)$ & $<0.0001$ & 0.0005 & NS & 0.0130 & NS \\
CN number $^{3}$ & NS & 0.0169 & NS & NS & NS \\
Lactose (\%) & 0.0103 & NS & NS & $<0.0001$ & NS \\
Fat (\%) & 0.0380 & $<0.0001$ & $<0.0001$ & NS & NS \\
Proteolysis (m $M$ Eq of Leu) & 0.0267 & NS & 0.0622 & NS & NS \\
Curd yield (g of DM/g) $_{\text {Coagulation time (min) }}$ & 0.0002 & NS & NS & NS & NS \\
\hline
\end{tabular}

${ }^{1}$ Results are presented as significance of the effects of cow, storage day, total bacteria count (TBC), separation of milk, and the interaction of separation of milk $\times$ storage day $(\mathrm{n}=66)$.

${ }^{2}$ The protein content in the whey fraction.

${ }^{3}$ Proportion of $\mathrm{CN}$ in relation to total protein. 
Table 5. Mean values of milk composition, proteolysis, and coagulation properties of cow-composite and cowseparated milk samples on different days of storage $(n=11)$

\begin{tabular}{|c|c|c|c|c|c|c|}
\hline \multirow[b]{2}{*}{ Property } & \multicolumn{2}{|c|}{ Storage d 0} & \multicolumn{2}{|c|}{ Storage d 2} & \multicolumn{2}{|c|}{ Storage d 5} \\
\hline & $\begin{array}{c}\text { Cow } \\
\text { composite }\end{array}$ & $\begin{array}{c}\text { Cow } \\
\text { separated }\end{array}$ & $\begin{array}{c}\text { Cow } \\
\text { composite }\end{array}$ & $\begin{array}{c}\text { Cow } \\
\text { separated }\end{array}$ & $\begin{array}{c}\text { Cow } \\
\text { composite }\end{array}$ & $\begin{array}{c}\text { Cow } \\
\text { separated }\end{array}$ \\
\hline Total protein (\%) & 3.28 & 3.27 & 3.29 & 3.28 & 3.32 & 3.29 \\
\hline $\mathrm{CN}(\%)$ & 2.39 & 2.40 & 2.39 & 2.40 & 2.37 & 2.34 \\
\hline Whey fraction ${ }^{1}(\%)$ & 0.89 & 0.86 & 0.90 & 0.88 & 0.98 & 0.94 \\
\hline CN number ${ }^{2}$ & 0.73 & 0.74 & 0.74 & 0.74 & 0.71 & 0.71 \\
\hline Lactose $(\%)$ & 4.76 & 4.82 & 4.77 & 4.83 & 4.77 & 4.84 \\
\hline Fat $(\%)$ & 3.69 & 3.61 & 3.52 & 3.50 & 3.60 & 3.50 \\
\hline Proteolysis ( $\mathrm{m} M \mathrm{Eq}$ of Leu) & 0.54 & 0.58 & 0.52 & 0.50 & 0.59 & 0.53 \\
\hline Curd yield ( $\mathrm{g}$ of $\mathrm{DM} / \mathrm{g}$ ) & 0.14 & 0.14 & 0.13 & 0.11 & 0.12 & 0.12 \\
\hline Coagulation time (min) & 6.18 & 6.41 & 23.63 & 20.09 & 13.59 & 12.68 \\
\hline
\end{tabular}

${ }^{1}$ The protein content in the whey fraction.

${ }^{2}$ Proportion of $\mathrm{CN}$ in relation to total protein.

increased lipolysis, which generates a higher absorption at protein wavelength and, therefore, results in a higher value of total protein content.

During cold storage of milk, factors other than SCC and mastitis pathogens can affect the milk (e.g., other bacteria, mainly psychrotrophs). Proteinases and lipases originating from psychrotrophic bacteria contribute to major spoilage of milk during storage (Sørhaug and Stepaniak, 1997; Haryani et al., 2003). In fact, the enzymes from the psychrotrophic bacteria might make a higher contribution to the spoilage of milk during storage than indigenous enzymes (Kelly et al., 2006). According to Leitner et al. (2008), the curd yield of milk from a healthy individual cow undergoes changes due to storage, which indicates that some proteolysis occurs, even in milk from healthy quarters. This is in accordance with our results, as we found an effect of storage on both proteolysis and curd yield in udderquarter milk samples irrespective of health status. In our study, the total bacteria count increased with duration of storage in all milk samples and, thus, contributed to decreased milk quality. Parameters affected by the total bacteria count were lactose and fat contents, $\mathrm{CN}$ number, proteolysis, and curd yield. However, the total psychrotroph count was not evaluated, but because the milk samples were stored at $+4^{\circ} \mathrm{C}$, it is likely that psychrotrophs grew during storage. Because the milk samples in our study were frozen before analysis of total bacteria count, it can be assumed that the number of bacteria might be decreased and, hence, the effect of total bacteria count could be underestimated (Read et al., 1969; Hubáčková and Ryšánek, 2007).

After only $2 \mathrm{~d}$ of storage, indications of alterations in milk composition and processing properties already occurred. In commercial milk production, the common procedure is for the farm to deliver milk to the dairy every second day. Our results indicate that by the time the milk is delivered to the dairy, the deterioration of milk quality has already started. Depending on the milk quality and udder health, the deterioration of milk quality in terms of protein degradation due to proteolysis by bovine proteases already starts in the udder (Sorensen et al., 2001), where the temperature is optimal, and requires an effective cool-chain thereafter to be minimized. However, the coagulation properties will, to some extent, be restored after pasteurization and, hence, some of the deterioration of milk quality can be prevented.

\section{Effect of SCC}

The elevated SCC in udder-quarter milk samples affected the total protein and lactose contents, protein content in the whey fraction, proteolysis, and curd yield. The changes in total protein, protein content in the whey fraction, and lactose content are well-known consequences of elevated SCC and mastitis. In severe mastitis, the proteolytic activity increases due to factors associated with the inflammation, which enhance the proteolytic activity of the milk, but also due to the effect of the mastitis pathogens. The increased permeability of the blood milk barrier and the increased SCC due to mastitis will increase the proteolytic activity of the milk (Bastian and Brown, 1996; Le Roux et al., 2003; Santos et al., 2003; Marino et al., 2005). The effect on milk composition and proteolysis is suggested to be dependent on the mastitis pathogen causing the infection (Leitner et al., 2006). Surprisingly, in our study, the curd yield seemed to be higher in udder quarters with elevated SCC. This is contrary to most other studies, which report a negative effect of mastitis on curd yield (Ali et al., 1980; Politis and Ng-Kwai-Hang, 1988a; Barbano et al., 1991; Ballou et al., 1995). The cheese yield from milk with high SCC is influenced by the losses of fat and protein in the whey during cheesemaking (Barbano et al., 1991). The results in our study 
might have been affected by the analytical method used, including the fact that the curd yield was measured as the yield of DM, in a relatively small amount of milk $(10 \mathrm{~mL})$, and in a relatively small number of samples. Another factor that influences the curd yield is the protein content, particularly $\mathrm{CN}$, which differs depending on the cow from which the milk is collected (Hallén et al., 2010). In addition, fat content is highly dependent on the diet but also on lactation stage and, hence, the cow from which the milk sample has been collected will affect the result (Sutton, 1989; Walstra et al., 1999). This was also shown in our study, as in udder-quarter, cow-composite, and cow-separated milk samples, the cow from which the milk was collected had an effect on $\mathrm{CN}$ and fat contents.

\section{Interaction Between SCC and Duration of Storage}

The total protein, CN, and fat contents; protein content in the whey fraction; and curd yield were significantly affected by the interaction of SCC and storage duration in udder-quarter milk samples. This indicates that these parameters reacted differently during storage depending on their SCC. The total protein content and protein content in the whey fraction appeared to increase to a higher extent in those samples with high SCC, whereas the $\mathrm{CN}$ content decreased. The fat content was higher in the affected udder quarters, but decreased during storage. It is uncertain how curd yield will react to storage in samples with elevated SCC, as milk from affected udder quarters showed a tendency to be higher in curd yield after $5 \mathrm{~d}$ of storage than milk from their healthy counterparts. Because an interaction effect of SCC and storage on total protein content, CN content, protein content in the whey fraction, and fat content occurred, it could be suggested that, in these parameters, the spoilage due to storage was enhanced by elevated SCC. From a practical point of view, this indicates that milk with elevated SCC has a lower ability to be stored. In our study this could only be seen in udder-quarter milk samples, but Leitner et al. (2008) suggested that biochemical reactions due to subclinically infected cows affected the quality and storage characteristics of the milk in bulk tanks. Our finding of enhanced deterioration of milk quality in milk with high SCC during storage is in agreement with Barbano et al. (2006), who found the CN degradation to be higher in milk with high SCC than in milk with low SCC during storage.

\section{Coagulation Properties}

A significant effect of storage on coagulation time was found in cow-composite and cow-separated milk samples. A numerical increase in mean values of coagulation time occurred after $2 \mathrm{~d}$ of storage, but with further storage this decreased. However, no significant effect of storage on coagulation time was observed in udder-quarter samples, although the numerical values increased with storage, which might be explained by a high variation in those milk samples. O'Brien et al. (2001) found shorter coagulation time in milk stored for $144 \mathrm{~h}$ compared with milk stored for either 72 or $0 \mathrm{~h}$. They also found that milk stored for 72 or $144 \mathrm{~h}$ had lower curd firmness 60 min after rennet addition than milk stored for $0 \mathrm{~h}$. This indicates that shorter coagulation time is not necessarily associated with better curd firmness as also observed by Wedholm et al. (2006). A similar phenomenon of decreased coagulation time due to storage was also seen in a study by Leitner et al. (2008). The increasing total bacteria count might have contributed to the decrease in coagulation time, as proteinases from psychrotrophic bacteria have milk clotting activity and degrade $\kappa_{-}, \alpha_{\mathrm{s} 1^{-}}$, and $\beta-\mathrm{CN}$ (Sørhaug and Stepaniak, 1997).

However, in our study, we did not observe the effect of SCC on coagulation time reported in other studies (Ali et al., 1980; Politis and Ng-Kwai-Hang, 1988b; O'Brien et al., 2001). A common feature in all of those studies was that coagulation time significantly increased at cow level when SCC increased, to above 436,000, 1 million, and 2 million cells $/ \mathrm{mL}$, respectively. Leitner et al. (2008) found no correlation between SCC and coagulation time in either milk from individual cows or milk from bulk tanks. This indicates that the increase in SCC needs to be rather high before any measurable effect on coagulation time occurs. Most of the samples with elevated SCC in our study had only a low-to-moderate increase, and the mean value of all cow-composite milk samples did not exceed 500,000 cells/mL, which could be one explanation for the lack of relationship between SCC and coagulation time. Another explanation could be the analytical method used here for measuring coagulation time, which consisted of recording visible flocculation of the milk after rennet addition. Due to practical circumstances, variation occurred in the time for which the milk samples were warmed, which could have affected the results.

\section{CONCLUSIONS}

Separation of milk from udder quarters with elevated SCC was shown to affect the total protein and lactose contents and protein content in the whey fraction at cow level. Milk quality can be improved by separation of milk at the udder-quarter level. In addition, milk quality, in terms of some parameters, was found to deteriorate much faster during storage, owing to increased 
SCC in milk at udder-quarter level. Milk composition, proteolysis, and coagulation properties were affected by SCC, as well as storage time and total bacteria count. This shows the importance of producing milk with high hygiene from healthy cows throughout production.

\section{REFERENCES}

Akers, R. M. 2002. Lactation and the mammary gland. Iowa State Press, Iowa.

Ali, A. E., A. T. Andrews, and G. C. Cheeseman. 1980. Influence of elevated somatic cell count on casein distribution and cheesemaking. J. Dairy Res. 47:393-400.

Auldist, M. J., S. Coats, B. J. Sutherland, J. J. Mayes, G. H. McDowell, and G. L. Rogers. 1996. Effects of somatic cell count and stage of lactation on raw milk composition and the yield and quality of Cheddar cheese. J. Dairy Res. 63:269-280.

Auldist, M. J., and I. B. Hubble. 1998. Effects of mastitis on raw milk and dairy products. Aust. J. Dairy Technol. 53:28-36.

Ballou, L. U., M. Pasquini, R. D. Bremel, T. Everson, and D. Sommer. 1995. Factors affecting herd milk composition and milk plasmin at four levels of somatic cell counts. J. Dairy Sci. 78:2186-2195.

Barbano, D. M., Y. Ma, and M. V. Santos. 2006. Influence of raw milk quality on fluid milk shelf life. J. Dairy Sci. 89(Suppl. 1):E15E19.

Barbano, D. M., R. R. Rasmussen, and J. M. Lynch. 1991. Influence of milk somatic cell count and milk age on cheese yield. J. Dairy Sci. 74:369-388.

Bastian, E. D., and R. J. Brown. 1996. Plasmin in milk and dairy products: An update. Int. Dairy J. 6:435-457.

Berglund, I., G. Pettersson, K. Östensson, and K. Svennersten-Sjaunja. 2004. Frequency of individual udder quarters with elevated CMT scores in cows' milk samples with low somatic cell counts. Vet. Rec. 155:213.

Deeth, H. C. 2006. Lipoprotein lipase and lipolysis in milk. Int. Dairy J. 16:555-562.

Forsbäck, L., H. Lindmark-Månsson, A. Andrén, M. Åkerstedt, and K. Svennersten-Sjaunja. 2009. Udder quarter milk composition at different levels of somatic cell count in cow composite milk. Animal 3:710-717.

Forsbäck, L., H. Lindmark-Månsson, A. Andrén, and K. SvennerstenSjaunja. 2010. Evaluation of quality changes in udder quarter milk from cows with low-to-moderate somatic cell counts. Animal 4:617-626.

Halasa, T., K. Huijps, O. Østerås, and H. Hogeveen. 2007. Economic effects of bovine mastitis and mastitis management: A review. Vet. Q. 29:18-31.

Hallén, E., A. Lundén, T. Allmere, and A. Andrén. 2010. Casein retention in curd and loss of casein into whey at chymosin-induced coagulation of milk. J. Dairy Res. 77:71-76.

Harding, F. 1995. The impact of raw milk quality on product quality. Pages 102-110 in Milk Quality. Blackie Academic \& Professional, London, UK.

Haryani, S., N. Datta, A. J. Elliott, and H. C. Deeth. 2003. Production of proteinases by psychrotrophic bacteria in raw milk stored at low temperature. Aust. J. Dairy Technol. 58:15-20.

Hortet, P., and H. Seegers. 1998. Loss in milk yield and related compositional changes resulting from clinical mastitis dairy cows. Prev. Vet. Med. 37:1-20.

Hubáčková, M., and D. Ryšánek. 2007. Effects of freezing milk samples on the recovery of alimentary pathogens and indicator microorganisms. Acta Vet. (Brno) 76:301-307.

Kelly, A. L., F. O'Flaherty, and P. F. Fox. 2006. Indigenous proteolytic enzymes in milk: A brief overview of the present state of knowledge. Int. Dairy J. 16:563-572.
Kitchen, B. J. 1981. Review of the progress of dairy science: Bovine mastitis: Milk compositional changes and related diagnostic tests. J. Dairy Res. 48:167-188.

Koskinen, M. T., J. Holopainen, S. Pyörälä, P. Bredbacka, A. Pitkälä, H. W. Barkema, R. Bexiga, J. Roberson, L. Sølverød, R. Piccinini, D. Kelton, H. Lehmusto, S. Niskala, and L. Salmikivi. 2009. Analytical specificity and sensitivity of a real-time polymerase chain reaction assay for identification of bovine mastitis pathogens. J. Dairy Sci. 92:952-959.

Le Roux, Y., F. Laurent, and F. Moussaoui. 2003. Polymorphonuclear proteolytic activity and milk composition change. Vet. Res. 34:629-645.

Leitner, G., O. Krifucks, U. Merin, Y. Lavi, and N. Silanikove. 2006. Interactions between bacteria type, proteolysis of casein and physico-chemical properties of bovine milk. Int. Dairy J. 16:648-654.

Leitner, G., N. Silanikove, S. Jacobi, L. Weisblit, S. Bernstein, and U. Merin. 2008. The influence of storage on the farm and in dairy silos on milk quality for cheese production. Int. Dairy J. 18:109-113.

Marino, R., T. Considine, A. Sevi, P. L. H. McSweeney, and A. L. Kelly. 2005. Contribution of proteolytic activity associated with somatic cells in milk to cheese ripening. Int. Dairy J. 15:1026-1033.

Munro, G. L., P. A. Grieve, and B. J. Kitchen. 1984. Effects of mastitis on milk yield, milk composition, processing properties and yield and quality of milk products. Aust. J. Dairy Technol. 39:7-16.

O'Brien, B., W. J. Meaney, D. McDonagh, and A. Kelly. 2001. Influence of somatic cell count and storage interval on composition and processing characteristics of milk from cows in late lactation. Aust. J. Dairy Technol. 56:213-218.

Politis, I., and K. F. Ng-Kwai-Hang. 1988a. Association between somatic cell count of milk and cheese-yielding capacity. J. Dairy Sci. 71:1720-1727.

Politis, I., and K. F. Ng-Kwai-Hang. 1988b. Effects of somatic cell counts and milk composition on the coagulating properties of milk. J. Dairy Sci. 71:1740-1746.

Read, R. B., J. G. Bradshaw, and D. W. Francis. 1969. Effects of freezing raw milk on standard plate count. J. Dairy Sci. 52:1720-1723.

Roupas, P. 2001. On-farm practices and post farmgate processing parameters of milk for cheesemaking. Aust. J. Dairy Technol. $56: 219-232$.

Santos, M. V., Y. Ma, and D. M. Barbano. 2003. Effect of somatic cell count on proteolysis and lipolysis in pasteurized fluid milk during shelf-life storage. J. Dairy Sci. 86:2491-2503.

SAS Institute. 2004. SAS/STAT 9.1 User's Guide. SAS Institute Inc., Cary, NC.

Sjaunja, L. O. 1984. Studies on milk analyses of individual cow milk samples. III. The effect of different treatments on infrared analyses. Acta Agric. Scand. A Anim. Sci. 34:273-285.

Sorensen, A., D. D. Muir, and C. H. Knight. 2001. Thrice-daily milking throughout lactation maintains epithelial integrity and thereby improves milk protein quality. J. Dairy Res. 68:15-25.

Sørhaug, T., and L. Stepaniak. 1997. Psychrotrophs and their enzymes in milk and dairy products: Quality aspects. Trends Food Sci. Technol. 8:35-40.

Spörndly, R. 2003. Feed Tables for Ruminants 2003 (Fodertabeller för idisslare 2003). Dept. of Animal Nutrition and Management, SLU Swedish Univ. Agric. Sci., Uppsala, Sweden.

Sutton, J. D. 1989. Altering milk composition by feeding. J. Dairy Sci. 72:2801-2814.

Walstra, P., T. J. Geurts, A. Noomen, A. Jellema, and M. A. J. S. van Boekel. 1999. Dairy Technology. Marcel Dekker Inc., New York, NY.

Wedholm, A., L. B. Larsen, H. Lindmark Månsson, A. H. Karlsson, and A. Andrén. 2006. Effect of protein composition in the cheesemaking properties of milk from individual dairy cows. J. Dairy Sci. 89:3296-3305.

Wiking, L., M. B. Frøst, L. B. Larsen, and J. H. Nielsen. 2002. Effects of storage condition on lipolysis, proteolysis and sensory attributes in high quality raw milk. Milchwissenschaft 57:190-194. 